\title{
MANAGING VOCATIONAL EDUCATION TO FACILITATE THE EMPLOYABILITY OF GRADUATES
}

\author{
Anita Līce \\ University of Latvia, Latvia
}

\begin{abstract}
Ensuring employability of graduates has become important issue in education considering the rapid changes and increasing uncertainty in the labour market. The aim of this research is, on the basis of the interviews with the managers of vocational education institutions, to find which aspects of vocational education management processes in Latvia are implemented successfully and which - require improvements in order to facilitate employability of graduates. The research methods include literature review and in-depth, semi-structured interviews with the managers (directors or deputy directors) of vocational education institutions in Latvia $(n=12)$. Data obtained were analysed according to consensual qualitative research procedure. The results of the analysis show that the most successful aspects in vocational education management processes with regards to facilitating graduate employability are linked to recent reforms in vocational education. Most important weaknesses which require improvements are linked to the lack of stability and coordination, problems related to education funding model, teachers, students, as well as the lack of labour market partners in providing work placements and work-based learning. The results provide overview of the current challenges in vocational education in Latvia and allow to plan improvements to facilitate employability of graduates.
\end{abstract}

Keywords: employability, management, processes, vocational education.

\section{Introduction}

Ensuring employability of graduates is one of the central questions in vocational education (VE) policy making and management. According to Yorke and Knight (2004), employability is "a set of achievements - skills, understandings and personal attributes - that make graduates more likely to 
gain employment and be successful in their chosen occupations" (Yorke \& Knight, 2004, 3). Therefore, employability is about both, getting a fulfilling initial job and being successful in the labour market in the long-term, which requires constant adaptability and learning. To support development of employability in students, vocational education institutions (VEIs) can ensure not just the acquisition of professional skills and experience, but also offer the career education, the development of general and emotional competences, as well as understandings and attitudes that are important for individual employability (Pool \& Sewell, 2014). For example, most valued individual employability attributes among Latvian employers are attitude to work, ability to work independently, work motivation, ability to take responsibility, problem solving skills, ability to adapt, to work in a team and communication skills (Lice, Sloka, 2019a).

Although the goal of VE is to educate graduates for the labour market, data indicates about weaknesses in how VE ensures employability of graduates both in the short, and in the long term. 20\% (or 5.4 of 27.1 thousands) of VE students did not complete their studies in the 2017/2018 study year (Ministry of Education and Science, 2019). Although work-placements organised within VE programmes can provide valuable learning and working experience to students and significantly enhance their employability (Lice, 2018), the quality of work-placements in Latvia varies. One in four students thought that his or her work-placement did not provide useful knowledge and skills for work in occupation. $37 \%$ of trainees didn't want to stay to work in the same company where they had work placement, every fifth of them - because they were not interested in their occupation (Klāsons \& Spuriņš, 2015), indicating to inefficient linkage between VE, work-placements and prospective career of students. Among those who graduated, $24 \%$ continued their work or studies in other field (Ministry of Education and Science, 2018) indicating to low relevance of VE to graduates. According to Lice and Sloka (2019), VEIs in Latvia perform only on a moderate level in developing employability competencies in their graduates.

Although the VE reform has triggered some activity of VEIs in ensuring adult learning opportunities, this area of activity is only developing. Unemployment of adults with vocational qualifications is rather a concern of public employment service which provides retraining opportunities. According to the data of the Employment Agency of Latvia (2018, 2019), the biggest share of the unemployed people is those with vocational qualifications, majority of them - at least 40 years old. Evidence shows that it is not a problem only in Latvia. Hanushek, Schwerdt, Woessmann, and Zhang (2017) compared employment rates across different ages for people with general education and vocational qualifications for 11 countries and 
found strong and robust support for a trade-off between better school-towork transition for VE graduates and better labour market outcomes later in life for general education graduates. The skills generated by VE may facilitate the transition into the labour market but may become obsolete at a faster rate. Although participation in adult learning is important for employability throughout career, people who have completed secondary education level, including VE, are significantly less active adult learners comparing to higher education graduates (Central Statistical Bureau, 2018). Moreover, average adult participation in lifelong learning in Latvia is very low: $7.3 \%$ of adults of age 25-64, while in the European Union (EU) 10.8\% (European Commission, 2017).

To facilitate employability of graduates, appropriate management of VE is needed. Therefore, the aim of this research is to find, which processes in the management of VE in Latvia are implemented successfully and which require improvements, using the exploratory qualitative research methods.

\section{Methodology}

Semi-structured, in-depth, 40 to 90 minutes long interviews with the managers of VEIs were conducted in 2018. In total, 12 interviews were conducted with 15 directors or deputy directors from 12 public VEIs (out of 34 public VEIs in Latvia). The VEIs were selected to ensure appropriate representation of all regions of Latvia, different VE fields, levels (secondary and college level) and institutional subordination (Ministry of Education and Science and municipalities). Interviews were structured into five themes: (1) planning and governance; (2) implementing education; (3) transfer from education to the labour market; (4) monitoring quality, ensuring feedback loop and continuous improvement; (5) providing adult learning. The interviewees were invited to comment the successful aspects and the necessary improvements in different VE management processes to ensure better employability of VE graduates. The items for the questionnaire were developed, based on the literature review. They were also asked additional questions on the importance of the goal of facilitating graduate employability to their institutions and the methods to achieve this goal. Data were analysed according to the consensual qualitative research procedure (Spangel, Liu, \& Hill, 2012) because of the exploratory and inductive aim of the research. First, the researcher went through the interview transcripts and identified domains of successful aspects and weaknesses in VE management processes. Second, the categories were identified, and data coded accordingly. Third, the frequencies of reasons for the successes and weaknesses $(\mathrm{Ni})$ in $\mathrm{VE}$ management processes were calculated and the most recurrent ones were identified. 


\section{Results and Discussions}

The results of the interviews showed that employability is very important goal for VEIs. The mean evaluation of importance of employability on a scale from $1-10$ was 9.5 with a range of only $2(n=15)$. The main methods of facilitating employability of graduates were work placements and work-based learning (WBL), as well as extra-curriculum activities.

The analysis of the interviews pointed out to the existence of 18 distinct domains of successful aspects and 25 distinct domains of weaknesses in VE management processes.

Most frequently mentioned domains of successful aspects in VE management that facilitates employability of graduates were: "teacher education" ( $\mathrm{Nm}=19)$ (mainly because of diverse offer of further education courses $(\mathrm{Ni}=8)$ and courses organised by VEIs themselves $(\mathrm{Ni}=3)$ ), "ensuring relevant adult education opportunities" $(\mathrm{Nm}=18)$ (mainly due to developing offer, based on demands of employers $(\mathrm{Ni}=6)$ and attempts to maintain the link to graduates (e.g., graduate days, informing about education opportunities, inviting to events) $(\mathrm{Ni}=4)$ ), "cooperation with labour market partners" ( $\mathrm{Nm}=15)$ (mainly due to successful cooperation with the Sectorial expert councils and employer organisations $(\mathrm{Ni}=6)$ ), "ensuring relevant education programmes" ( $\mathrm{Nm}=15)$ (mainly due to regularly updating education programmes according to labour market needs ( $\mathrm{Ni}=8)$, involving employers in developing $\mathrm{VE}$ programmes $(\mathrm{Ni}=4)$ and modernised infrastructure $(\mathrm{Ni}=3)$ ), "providing work experience" ( $\mathrm{Nm}=15)$ (mainly due to WBL, based on good cooperation with employers ( $\mathrm{Ni}=8)$ ) and "capacity to ensure adult education" $(\mathrm{Nm}=12)$ (mainly due to the project on adult education, co-financed by EU funds $(\mathrm{Ni}=4)$. Other mentioned successful aspects were: considering labour market demands in $\mathrm{VE}(\mathrm{Ni}=4)$, development of employability competencies in VE $(\mathrm{Ni}=5)$, project on career education, co-finances by EU funds $(\mathrm{Ni}=5)$ and collecting information about graduate employment $(\mathrm{Ni}=4)$.

Many of these aspects are linked to recent reforms in VE, as well as the activities implemented within the projects, co-financed by the EU funds, for example, modernising the infrastructure of VEIs, establishment of the Sectorial expert councils, reviewing and updating occupational standards, developing modular learning programmes, offering career education to students, offering adult learning opportunities, supporting development of WBL.

When it comes to existing weaknesses in the VE management processes, the most significant weaknesses with the number of mentions of at least 10 were the following: the lack of stability, the lack of leadership and 
coordination, problems related to VE financing model, problems related to teachers, problems related to students and the lack of labour market partners offering work-placements and WBL. An overview of identified weaknesses and reasons for weaknesses is provided in Table 1.

\section{Table 1. Overview of domains and reasons of weaknesses in VE management in Latvia}

\begin{tabular}{|c|c|}
\hline Domains of weaknesses $\left(\mathrm{Nm}^{*}\right)$ & Reason of weaknesses (subcategories) $\left(\mathrm{Ni}^{* *}\right.$ ) \\
\hline \multicolumn{2}{|c|}{ 1. Planning and governance (total $\mathrm{Nm}=59$ ) } \\
\hline 1.1. Lack of stability $(\mathrm{Nm}=14)$ & $\begin{array}{l}\text { Lack of long-term planning, strategy }(\mathrm{Ni}=5) \\
\text { Constant process of reforms }(\mathrm{Ni}=3) \\
\text { Frequent changes in priorities }(\mathrm{Ni}=3) \\
\text { Too high workload }(\mathrm{Ni}=2)\end{array}$ \\
\hline $\begin{array}{l}\text { 1.2. Lack of leadership and } \\
\text { coordination }(\mathrm{Nm}=10)\end{array}$ & $\begin{array}{l}\text { Lack of mutual coordination, hasty } \\
\text { implementation of EU projects }(\mathrm{Ni}=5) \\
\text { Conflicting procedures in EU projects }(\mathrm{Ni}=3)\end{array}$ \\
\hline $\begin{array}{l}\text { 1.3. Problems related to funding } \\
\text { system }(\mathrm{Nm}=14)\end{array}$ & $\begin{array}{l}\text { Public financing does not cover real costs } \\
(\mathrm{Ni}=3) \\
\text { Promotes competition among educational } \\
\text { institutions }(\mathrm{Ni}=2) \\
\text { Low teacher salaries }(\mathrm{Ni}=2)\end{array}$ \\
\hline \multicolumn{2}{|l|}{$\begin{array}{l}\text { 1.4. Problems related to } \\
\text { regulation }(\mathrm{Nm}=2)\end{array}$} \\
\hline 1.5. Low VE prestige $(\mathrm{Nm}=6)$ & Persistent stereotypes about VE $(\mathrm{Ni}=3)$ \\
\hline 1.6. Lack of support $(\mathrm{Nm}=6)$ & $\begin{array}{l}\text { Lack of methodological support }(\mathrm{Ni}=2) \\
\text { Lack of support by municipalities }(\mathrm{Ni}=2)\end{array}$ \\
\hline $\begin{array}{l}\text { 1.7. Labour market requirements } \\
\text { and future skills needs } \\
(\mathrm{Nm}=7)\end{array}$ & $\begin{array}{l}\text { Lack of future skills needs planning in the long } \\
\text { term }(\mathrm{Ni}=3) \\
\text { Insufficient understanding by/ cooperation with } \\
\text { the sectorial expert councils }(\mathrm{Ni}=2) \\
\text { Too high requirements by employers }(\mathrm{Ni}=2)\end{array}$ \\
\hline \multicolumn{2}{|c|}{ 2. Implementing education (total $\mathrm{Nm}=44$ ) } \\
\hline $\begin{array}{l}\text { 2.1. Problems related to } \\
\text { teachers }(\mathrm{Nm}=18)\end{array}$ & $\begin{array}{l}\text { Inappropriate qualification requirements } \\
(\mathrm{Ni}=5) \\
\text { Lack of teachers, especially of vocational } \\
\text { courses, outside of Riga }(\mathrm{Ni}=4) \\
\text { Low capacity of teachers to ensure quality } \\
\text { teaching }(\mathrm{Ni}=3) \\
\text { High average age of teachers }(\mathrm{Ni}=2) \\
\text { Inappropriate further teacher education } \\
(\mathrm{Ni}=2)\end{array}$ \\
\hline \multicolumn{2}{|l|}{$\begin{array}{l}\text { 2.2. Problems related to } \\
\text { education programme } \\
(\mathrm{Nm}=3)\end{array}$} \\
\hline $\begin{array}{l}\text { 2.3. Contemporary teaching } \\
(\mathrm{Nm}=2)\end{array}$ & $\begin{array}{l}\text { Lack of modern equipment for learning, } \\
\text { especially in small institutions }(\mathrm{Ni}=2)\end{array}$ \\
\hline
\end{tabular}




\begin{tabular}{|c|l|}
\hline Domains of weaknesses $(\mathbf{N m} *)$ & \multicolumn{1}{|c|}{ Reason of weaknesses (subcategories) $\left(\mathbf{N i}^{* *}\right)$} \\
\hline $\begin{array}{c}\text { 2.4. Modular programmes } \\
(\mathrm{Nm}=5)\end{array}$ & $\begin{array}{l}\text { Unclear methodologies }(\mathrm{Ni}=3) \\
\text { Doesn't change anything in essence }(\mathrm{Ni}=2)\end{array}$ \\
\hline $\begin{array}{c}\text { 2.5. Problems related to students } \\
(\mathrm{Nm}=15)\end{array}$ & $\begin{array}{l}\text { High drop-out rate } \mathrm{Ni}=4) \\
\text { Low prior education level }(\mathrm{Ni}=3) \\
\text { Motivation of students }(\mathrm{Ni}=3) \\
\text { Low socioeconomic status }(\mathrm{Ni}=2)\end{array}$ \\
\hline
\end{tabular}

\section{Transfer from education to the labour market (total $\mathrm{Nm}=24$ )}

3.1. Lack of employment opportunities $(\mathrm{Nm}=3)$

3.2. Lack of labour market partners $(\mathrm{Nm}=14)$

Lack of jobs for young graduates $(\mathrm{Ni}=2)$

Lack of companies providing work-placements or WBL $(\mathrm{Ni}=5)$

Too restrictive WBL regulation $(\mathrm{Ni}=4)$

Lack of support by professional/employers'

associations $(\mathrm{Ni}=2)$

\subsection{Quality of practical learning $(\mathrm{Nm}=2)$ \\ 3.4. Career support $(\mathrm{Nm}=3)$}

3.5. Recognising prior learning $(\mathrm{Nm}=2)$

4. Monitoring quality, ensuring feedback loop and continuous improvement (total $\mathrm{Nm}=13$ )

4.1. Problems related to qualification evaluation $(\mathrm{Nm}=3)$

Decentralized examination committees do not guarantee similar requirements, lack of objectivity $(\mathrm{Ni}=2)$

4.2. Problems related to quality Accreditation does not support development $\begin{array}{ll}\text { assurance }(\mathrm{Nm}=6) & (\mathrm{Ni}=3)\end{array}$

Too bureaucratic procedures $(\mathrm{Ni}=2)$

4.3. Problems related to collecting feedback $(\mathrm{Nm}=3)$

Lack of information about employment of graduates in the longer term $(\mathrm{Ni}=2)$

\section{Providing adult learning (total $\mathrm{Nm}=11$ )}

\begin{tabular}{|c|l|}
$\begin{array}{c}\text { 5.1. Involvement in EU project } \\
\text { on adult learning }(\mathrm{Nm}=4)\end{array}$ & $\begin{array}{l}\text { Unmotivating conditions for institutions and } \\
\text { teachers to participate in EU project on adult } \\
\text { learning }(\mathrm{Ni}=3)\end{array}$ \\
$\begin{array}{l}\text { 5.2. Lack of demand for adult } \\
\text { learning }(\mathrm{Nm}=4)\end{array}$ & $\begin{array}{l}\text { Limited demand, adults and employers not } \\
\text { ready to finance adult learning }(\mathrm{Ni}=2)\end{array}$ \\
\hline 5.3. Capacity of VEIs $(\mathrm{Nm}=3)$ & $\begin{array}{l}\text { Teachers are not prepared to work with adults } \\
(\mathrm{Ni}=2)\end{array}$ \\
\hline
\end{tabular}

${ }^{*} \mathrm{Ni}=$ number of VEIs evoking the weakness, $\max (\mathrm{Ni})=12$. Reasons with $\mathrm{Ni}=1$ are not included in the table

$* * N m=$ number of mentions. Domains with $\mathrm{Nm}=1$ are not included in the table Source: Author's analysis, based on the interviews with the managers of VEIs, conducted in 2018 $(n=12)$ 
In the area of planning and governance, most important domains of weaknesses were the problems related to funding system $(\mathrm{Nm}=14)$, lack of stability $(\mathrm{Nm}=14)$ and lack of leadership and coordination $(\mathrm{Nm}=10)$.

Although the managers mostly agreed that the funding system of VE was problematic, the reasons they highlighted were very different. Most frequently mentioned reasons were that public financing did not cover real costs of implementing quality education, that it promoted undesirable competition among educational institutions and that teacher salaries were too low.

Most important reasons for the lack of stability in governance and management of VE were the lack of long-term planning, constant process of reforms and frequent changes in priorities. This was also closely linked to the lack of leadership and coordination due to the lack of mutual coordination and hasty implementation of the EU-funded projects, as well as sometimes conflicting procedures. In this area, the managers also pointed out to other reasons of weaknesses that hindered development of VE: the lack of researching and considering the labour market requirements and future skill needs $(\mathrm{Nm}=7)$, the lack of support from central and regional governments $(\mathrm{Nm}=6)$ and low VE prestige $(\mathrm{Nm}=5)$.

In the area of implementing education, the most important domains of weaknesses were the problems related to teachers $(\mathrm{Nm}=18)$ and students $(\mathrm{Nm}=15)$. They were concerned by the lack of teachers, especially for vocational courses ( $\mathrm{Ni}=4)$, mainly due to uncompetitive teacher salaries comparing to other jobs in the labour market. Indeed, according to OECD (2014), the average salaries for secondary education teachers in OECD countries after 15 years of experience are 124-129\% of GDP per capita, while in Latvia - just 52\% of GDP per capita (OECD, 2014, 34). The managers also believed that the official qualification requirements for teachers $(\mathrm{Ni}=5)$ are inappropriate and limit their ability to attract new teachers. Few of them also mentioned low capacity of teachers to ensure quality teaching, including resistance to improve their competencies $(\mathrm{Ni}=3)$. Regarding problems with students, the managers pointed out to the following reasons: high dropout rate $(\mathrm{Ni}=4)$, low prior education level $(\mathrm{Ni}=3)$, low motivation $(\mathrm{Ni}=3)$ and low socioeconomic status $(\mathrm{Ni}=2)$. Managers were also concerned by the implementation of modular programmes in VE $(\mathrm{Nm}=5)$, mainly due to unclear methodology.

In the area of transfer from education to the labour market, the main domain for concerns was the lack of labour market partners $(\mathrm{Nm}=14)$. The main reasons for that were the lack of companies providing workplacements or WBL $(\mathrm{Ni}=5)$, too restrictive regulations of WBL $(\mathrm{Ni}=4)$ and the lack of support by professional or employers' associations $(\mathrm{Ni}=2)$. 
In the area of monitoring quality, ensuring feedback loop and continuous improvement, the managers didn't have any serious concerns. The following negative aspects were mentioned: accreditation procedure did not support development, but rather just monitored the compliance to minimum standards $(\mathrm{Ni}=3)$. Managers of two institutions also pointed out to the fact that the decentralised system of professional qualification exams did not provide comparable, objective evaluation of learning outcomes $(\mathrm{Ni}=2)$ and to the lack of information about employment of graduates in the longer term, not just immediately after graduation, $(\mathrm{Ni}=2)$.

In the area of adult learning, there were no serious concerns either. The following negative aspects were mentioned: unmotivating conditions for institutions and teachers to participate in the EU-funded project on adult learning $(\mathrm{Ni}=3)$, limited demand and unwillingness to finance adult learning by adult learners and employers $(\mathrm{Ni}=2)$ and that teachers were not prepared to work with adults $(\mathrm{Ni}=2)$.

The research results showed that the main improvements are needed in the area of mutual collaboration between the national and institutional level, especially when it comes to bottom-up communication and mutually coordinated implementation of reforms and projects; including the lack of guidance and support to VEIs. Although recent improvements in VE system and especially the opportunities provided by the EU-funded projects were much appreciated, VEIs feel overwhelmed by the uninterrupted, parallellytaking place and uncoordinated changes. The financing system of VE should be reviewed to support intentions of the reform, including ensuring flexible learning paths and adult learning provision. It should cover real costs of implementing quality education, including more competitive teacher salaries to ensure availability of qualified, good teachers. It should preferably also motivate VEIs to work towards their strategic goals and reward results, as well as motivate to co-operate rather than compete. The diverse learning needs of students should also be considered: supporting students with learning difficulties and students from low socioeconomic background require additional expenses. The processes that have been successfully started within the context of the reform should be further implemented, including co-operation with labour market partners, ensuring relevant education programmes, ensuring career education and adult learning opportunities. Improvements are needed in ensuring the quality of work placements and WBL and reducing drop-out rate, especially by ensuring support to students with learning difficulties and difficult socioeconomic conditions. 


\section{Conclusions}

The most successful aspects in VE management processes with regards to facilitating graduate employability are linked to recent reforms in VE, especially the EU-funded activities, for example, the modernised infrastructure of VEIs, updating occupational standards and reviewing programmes, implementing modular approach, establishing the Sectorial expert councils, ensuring teacher training opportunities, career education and adult learning opportunities.

Most important weaknesses in VE management processes are the lack of coordination of different processes related to VE reforms and EU-funded projects and the appropriate support to VEIs to successfully implement these activities, problems related to VE financing model, problems related to teachers (especially their availability and competence), problems related to students (especially prior knowledge, socio-economic background and motivation) and lack of labour market partners in providing work placements and WBL.

To improve the performance of VE in ensuring employability of graduates, the policy makers should consider reforming VE funding system to ensure that full costs of implementing quality VE are covered (including competitive teacher salaries) and good results of VEIs in terms of employability of students are rewarded (by implementing performancebased funding element). Targeted support activities for students from low socio-economic background and with learning difficulties should be implemented to reduce dropout and to ensure employability development for all students. Considering large dependence on the EU funds in the development of $\mathrm{VE}$, mechanisms to ensure sustainability of activities currently financed by the EU-funded projects should be ensured, including developing and updating occupational standards, modernising infrastructure, developing and updating modular learning programmes, ensuring career education and adult education, ensuring courses for teachers, supporting employer engagement in ensuring work placements and WBL. In addition, better coordination, information exchange and methodological support to VEIs is needed to successfully implement reforms.

\section{References}

Central Statistical Bureau. (2018). Apsekojuma "Pieaugušo izglïtiba" rezultāti [Results of the survey "Adult Education"]. Retrieved from https://www.csb.gov.lv/ lv/statistika/statistikas-temas/socialie-procesi/izglitiba/meklet-tema/303-apsekojumapieauguso-izglitiba-rezultati-2018

European Commission. (2017). Education and Training Monitor 2017. Luxembourg. https://doi.org/10.2766/180281 
Employment Agency of Latvia. (2018). Pārskats par bezdarba situāciju valstī. [Overview of the unemployment situation in the country] Riga. Retrieved from http://nva.gov.lv/ docs/31_5afec9ee727b98.06215069.pdf

Employment Agency of Latvia. (2019). Pārskats par bezdarba situāciju valstī. [Overview of the unemployment situation in the country] Riga. Retrieved from http://nva.gov.lv/ docs/31_5c5066faa142f5.77210853.pdf

Hanushek E. A., Schwerdt, G., Woessmann, L., Zhang, L. (2017). General Education, Vocational Education, and Labor-Market Outcomes over the Lifecycle. Journal of Human Resources, 52(1), 48-87.

Klāsons, G., Spurin̦š, U. (2015). Pētijums par prakšu pieejamību un kvalitāti Latvijā. Noslegguma zinojums. [Study on availability and quality of work placements in Latvia. Final report]. Riga: Employers' Confederation of Latvia (LDDK). Retrieved from http:// www.lddk.lv/wp-content/uploads/2015/06/LDDK_VET4E_Petijums_prakses.pdf

Lice, A. (2018). Learning by Working: Examining Examples of Good Practice in Organising Work placements in Vocational Education. "Learning Strategies and Constructionism in Modern Education Settings" by IGI Global publishing house, ISBN13: 9781522554301

Lice, A., Sloka, B. (2019). Performance of vocational education in Latvia in developing employability of graduates. In SOCIETY. INTEGRATION. EDUCATION. Proceedings of the International Scientific Conference. Volume 5, Rezekne, Rezekne Academy of Technologies, 2019, pp. 222-232.

Līce, A., Sloka, B. (2019a). Which skills, competencies and attitudes are employers looking for in recruitment process in Latvia? In Proceedings of the International Scientific Conference "Contemporary Issues in Business, Management and Economics Engineering", Vilnius, Lithuania, 2019, pp. 7-17. Retrieved from http://cibmee.vgtu.lt/index.php/ verslas/2019/paper/viewFile/477/186

Ministry of Education and Science. (2018). 2017.gada 13. decembra Profesionālās izglītības un nodarbinātības trīspusējās sadarbības apakšpadomes sēdes protokols. [Minutes of Vocational education and employment tripartite sub-council meeting 13 December 2017]. Ministry of Education and Science of Latvia. Retrieved from http:// izm.gov.lv/images/izglitiba_prof/Protokols-Nr.10-2017.gada-13.decembr.pdf

Ministry of Education and Science. (2019). Izglītojamo skaits profesionālās izglītības programmās 2018./2019. m.g. [Number of students in vocational education programmes in 2018/2019 study year]. Retrieved from https://izm.gov.lv/lv/publikacijas-un-statistika/ statistika-par-izglitibu/statistika-par-profesionalo-izglitibu/2018-2019-m-g-3

OECD. (2014). Teacher remuneration in Latvia: An OECD perspective. Retrieved from https://www.izm.gov.lv/images/statistika/petijumi/34.pdf

Pool, L. D., Sewell, P. (2007). The key to employability: developing a practical model of graduate employability. Education + Training, 49(4), 277-289.

Spangel, P. T., Liu, J., Hill, C. (2012). Consensual qualitative research for simple qualitative data: an introduction to CQR-M. Retrieved from https://www.researchgate.net/ publication/261872081_Consensual_Qualitative_Research_for_Simple_Qualitative_Data_ An_Introduction_to_CQR-M

Yorke, M., Knight, P. (2004). Embedding employability into the curriculum. Learning and Employability, 3, 1-28. 